\title{
as the Autobiographical Heresy
}

\section{1.}

This portion of the discussion shall focus on the statement by Karol Sauerland: "An essay should demand such focus as the act of reading a poem"2, which was included in the preface to the selection of studies by Theodor W. Adorno. However, it should not be considered directly by analysing the essence and the meaning of comparing the essay to poetry, but, rather, in reference to Jan Tomasz Gross' previous works, which utilised metaphors and complex structures, and which require multiple painstaking readings. Since the focus of the discussion indicated as the main one (or at least the first one) will be dominated by a study of Gross' central problem of Polish-Jewish relations during the Second World War, it is worth considering already at the beginning, if only superficially, the issues associated with the aesthetics; despite appearances, the style of argumentation applied by the author of

1 A fragment of Czapski's letter to Jan Tomasz Gross regarding his essay Ten jest z ojczyzny mojej, ale go nie lubię, discussed in this article, which was included in the collection Jan Tomasz Gross w rozmowie z Aleksandra Pawlicka “...bardzo dawno temu, mniej więcej w zeszły piątek...", Warsaw 2018, p. 135. [Unless indicated otherwise, quotations in English were translated from Polish]

${ }^{2}$ K. Sauerland, Wstęp, [in:] T.W. Adorno, Sztuka i sztuki. Wybór esejów, transl. K. Krzemień-Ojak, selection and introduction K. Sauerland, Warsaw 1990, p. 12. 
Sasiedzi has, in this case, a fundamental significance for all other properties of his text as it decides not only about how but also what was said in it.

The socio-political commentary-writing of the mid-1980s, to which Gross' Ten jest z ojczyzny mojej..., ale go nie lubię belongs - being the core topic of this study - has served as the foundation of the modern thinking about the attitude of Poles towards the Holocaust, both in notional terms and formal terms, so to speak. Apart from Jan Błoński's essay titled Biedni Polacy patrza na getto, there appeared a dozen or so other important texts by major Polish intellectuals, e.g. Andrzej Smolar, Jakub Karpiński, and Roman Zimand, which - in terms of the level of the formulation of thoughts and the degree of their complexity - were no different than the best philosophical essays of the first half of the 20th century. However, the influence of the erudite nature of those texts on modern times is negligible: almost no one remembers about any of those, yet Błoński is remembered far too well. The brilliant career of his text became one of the reasons why the other essays were forgotten. Yet the poetic nature or rather the complexity of the structure transitioning into the cognitive meanderings of Smolar's and Zimand's studies is worth more than one reading and it is visible even at the level of the very titles of the texts: Szoah, drugi upadek ${ }^{3}$ [Shoah: The Second Fall], Asymetria ${ }^{4}$ [Asymmetry], Tabu i niewinność ${ }^{5}$ [Taboo and Innocence], Piołun i popiót ${ }^{6}$ [Bitter Wormwood and Ash]. Some, like the title of Zimand's essay, have been absorbed by the Polish language in the form of lexicalised maxims. But is there anyone who still remembers their sources? The essays of the 1980s have been forgotten not only because Jan Błoński managed to close the decade and retain it in his text (in which, it seems, he did not succeed). It has been forgotten mostly because it proved too difficult, too demanding, requiring the already-mentioned painstaking repeated readings, which is not much different from the hermeneutics of a poem. Simply consider that Piołun i popiót implicitly referenced Czesław Miłosz' poetry (e.g. Gwiazda piotun) in order to understand that the discussed collection of essays includes an interpretative challenge much more difficult than the analysis of the bombastic sentence: "Bóg tę rękę zatrzymał"7 ["God stopped that hand"], which comes from an essay that - unlike the texts by Karpinski or Zimand - features transparent structures; most thoughts are formulated directly and quotations from poetry are 'on the surface'.

One such challenge, possibly most emphasised by Gross, concerns the changes introduced in the consecutive editions of the essay, which applied both to its structure and significance. One should realise that many of the texts I discuss in this article were created with the intention to be published in cultural and social periodicals, for debates conducted in weeklies and

3 P. Śpiewak, Szoah, drugi upadek, [in:] Przeciw antysemityzmowi 1936-2009, vol. 2, selection and introduction A. Michnik (ed.), Kraków 2010, pp. 934-948.

${ }^{4}$ J. Karpiński, Asymetria, [in:] Przeciw antysemityzmowi..., pp. 997-1006.

5 A. Smolar, Tabu i niewinność, [in:] Przeciw antysemityzmowi..., pp. 1030-1075.

${ }^{6}$ R. Zimand, Piołun i popiót. Czy Polacy i Żydzi wzajem się nienawidzą?, [in:] Przeciw antysemityzmowi..., pp. 1109-1160.

7 J. Błoński, Biedni Polacy patrza na getto, [in:] idem., Biedni Polacy patrza na getto, Kraków 2008 , p. 33. 
monthlies, and less often for academic purposes, such as symposia or conferences. The time of lively disputes, which the 1980s became, did not favour ready-made narratives; it did, however, favour essayistic narratives, and not in the traditionally hermeneutic meaning. In writing about poetry as the metaphor of the essay, Sauerland indicated that traditional methods of reading - which suggested the reading of the whole based on fragments - had fallen; instead, he suggested the reading of fragments independently, without the need to seek a conclusion or to find more than one summation or ending.

The 'putting together' of Zimand's and Gross' essays - the authors of sagacious revolutionary studies devoted to a part of Polish history which was avoided in the 1980s - proves difficult even today, and its utility has to be justified ${ }^{8}$. These are not essays of hard proof but of 'fancy' reasoning, often only later verified and corrected by historians who have at their disposal different notional tools and a much more precise methodology than the indicated essayists had. I am proposing to return to their works. This is not to overlook errors, but to reject the category of error as a whole, viewing the essay as an attempt at alternative thinking as opposed to science, which cannot produce an imperfect, incoherent, or non-model language, through which authors can pose fundamental breakthrough theses for the society.

\title{
2.
}

The discussion of the essay by Adorno in his study titled Esej jako forma [The Essay as Form], which was published in Polish in a collection from 1990, offered an important context for those writings. Let me mention one of its postulates regarding the differences between the genre specified in the title and science as such:

\begin{abstract}
Aktualność eseju jest aktualnością tego, co anachroniczne. Czas jest dla niego bardziej niełaskawy niż kiedykolwiek. Dostaje się on w tryby między zorganizowaną naukę, w której wszyscy uzurpują sobie prawo kontrolowania wszystkiego i wszystkich i która wyklucza tych nie przykrojonych na miarę consensusu z obłudną pochwałą dla tego, co intuicyjne i pobudzające. ${ }^{9}$
\end{abstract}

8 Cf. A. Calderón Puerta, T. Żukowski, Wina obojętności, [in:] Opowieść o niewinności. Kategoria świadka Zagłady w kulturze polskiej (1942-2015), eds. A. Calderón Puerta, K. Chmieleska, M. Hopfinger et al., Warsaw 2018, pp. 345-387. The authors of the study juxtaposed the essays by Błoński and Gross in order to compare the ways in which both authors discussed the topic of Polish culpability. This study indicated that the author of Widzieć jasno, w zachwyceniu appears to have repeated most of the anti-Jewish patterns present in the socio-political writings of his time, and to have analysed historical sources in a superficial manner, while Gross - who approached patterns and sources in a completely different way - indicated the many instances of reticence about the Polish culpability. Despite this, as argued by the discussed academic narrative, the main object of the study of the researchers was Błoński's failing: "He utilised a mode of thinking proposed by candid Catholics in the 1940s and he was successful. His position was treated by many as the final word in the matter of Polish culpability". A. Calderón Puerta, T. Żukowski, Wina obojętności, p. 385.

9 T.W. Adorno, Esej jako forma, [in:] T.W. Adorno, Sztuka i sztuki..., p. 98. [English version: T.W. Adorno, The Essay as Form, [in:] idem., Notes to Literature, Columbia University Press, New York 1991]. 
[The contemporary relevance of the essay is that of anachronism. The time is less favorable to it than ever. It is ground into pieces between an organised system of science and scholarship on the one side, in which everyone presumes to control everyone and everything and where everything not tailored to the current consensus is excluded while being praised hypocritically as "intuitive" and "stimulating".]

In Adorno's argument, the essay reaches the status of a discourse competing with science, which, on the one hand, wins with the latter, and, on the other - if incorrectly evaluated - it can be ruthlessly discredited by the proponents of truth and method. Not all texts which are essays send sufficiently clear essayistic signals, such as, e.g.: the title (in Gross' case, it is the subtitle of the collection, in which the discussed study was included), or genre reference (in Zimand's case, it is stated overtly ${ }^{10}$ in the language in which it was written ${ }^{11}$ and in the Polish translation ${ }^{12}$ ), but, mostly, a complex digressive structure (Śpiewak) intertwined with overt and covert quotations, paraphrases, and allusions to literature. Some Polish essays which raised the topic of the Holocaust conceal their genre affinity while not fitting into the model of scientific narrative due to a lack of a conclusion or the personal musings of their authors. The most distinct example of activities which violate the coherence of academic argumentation is Piołun i popiót, which offers several hypotheses simultaneously, a parallel course of the story, and a narrative which fulfils that which Adorno called the "anachronism" of the essay. In the case of Zimand's study, a major role was also played by the fact of undermining the illusion of a simple world, as the author of Minima moralia argued, so perfect "for defending that which is non-existent" ${ }^{13}$. Instead of offering proof of a known reality, the essay summons a non-existent reality which could exist, and which basically does exist yet it is not accepted, noticed, or recognised by everyone. By opposing the third Cartesian rule - i.e. "to conduct my thoughts in such an order that, by commencing with objects the simplest and easiest to know, I might ascend by little and little, and, as it were, step by step, to the knowledge of the more complex"14 - Adorno demands that readers should see in the essay a counter-narrative or, rather, an anti-scientific narrative, at the same time mocking a discipline which leads to nowhere, and a perfect instance of the truth, which acquires its prerogatives only by dint of appropriate presentation.

That detailed listing of the non-systemic qualities of the essay mainly serves to indicate that it became a more appropriate form for writing about the Polish-Jewish relations than any other form, including for the authors of later renowned academic studies, e.g. the already mentioned Gross, Śpiewak, and Zimand. Since the intentions behind this article are extremely

${ }_{10}$ Namely that it is an essay.

11 English 'essay', French 'essai'.

12 An attempt.

13 T.W. Adorno, Esej jako forma, p. 91.

${ }_{14}$ R. Descartes, Rozprawa o metodzie, transl. W. Wojciechowska, Warsaw 1981, vol. 22. As quoted in: T.W. Adorno, Esej jako forma, p. 90. 
modest and are limited mainly to a discussion of the difficulty in reading Gross' early essays - and only later to indicating the similarities and differences between the first version of Ten jest $z$ ojczyzny mojej... and the subsequent ones - I primarily wish to propose the consideration of the essay as a form of convenient reasonable thinking and the evolution of the form in Gross' works as the main problem. Later, I intend to answer the question about whether all the mental excursions and inconsistencies he proposed in those texts did not actually supplement Adorno's extensive theory, which discussed the value of over-interpretation and the value of discontinuity and fragments in the theory of cognition. The essay, as Adorno argued, displays independence in reference to the "priorities of fact"15; it rejects that which does not exist and turns to that which is not, but which might be. Considering the receptions of Piotun i popiót and Ten jest $z$ ojczyzny mojej (a few colleagues of Gross saw in the early version of the text the author's "mental aberration"16), one should conclude that both studies refer to heretic tradition $s^{17}$, i.e. these are intellectual excursions into the academic pathways of thinking about how one should profess history and write about the attitudes of Poles during World War Two.

\section{3.}

According to information provided by Gross in 1986, before Ten jest z ojczyzny mojej... was published in the Aneks periodical, the text had been altered three times: in 1980 when it was sent to the Res Publika periodical; the second time, in 1985, when Gross delivered it during a lecture in Oxford; and the third time in 1986 in Aneks. The first version was directly influenced by the polemic by Rafael Scharf and Andrzej Szczypiorski, which Gross read in 1979 in Kultura. Soon afterwards, the researcher prepared a response, which he sent to Res Publika, where it was supposed to be published along with a polemic commentary. Sadly, though, the commentary was never created, the study was not published, and the periodical closed down. In 1985, Gross presented a paper at a conference on Polish history, partly devoted to - judging from the context - the issues discussed in the text on which this article focuses. It stirred a tempestuous reaction. What happened next could be called a persistent work to sharpen the argumentation first challenged by the editorial board of Res Publika and, later, by the participants to the conference. A new version of the text was first presented at the Institute of Polish-Jewish Studies in Oxford, and later it was printed in Aneks, which placed it next to studies by Karpiński and by Smolar. That version was published in 2010 by Adam Michnik in the second volume of the Przeciw antysemityzmowi 1936-2010 anthology, disregarding the fact that in 1998, in the collection Upiorna dekada. Trzy eseje o stereotypach na temat Żydów, Polaków, Niemów

\footnotetext{
${ }^{15}$ Ibid., p. 95.

${ }_{16}$ J.T. Gross, Ten jest $z$ ojczyzny mojej..., ale go nie lubie, [in:] Przeciw antysemityzmowi 19362009, vol. 2, selection and introduction by A. Michnik (ed.), Kraków 2010, p. 1009.

${ }_{17}$ T.W. Adorno, Esej jako forma, p. 99.
} 
$i$ komunistów 1939-1948 ${ }^{18}$, another fourth version of the study was published. It is possible that the decision to publish the third version once the fourth version had been published was made by the author himself, yet he did not add any commentary on it even in a consecutive edition of Upiorna dekada in $2007^{19}$. When interpreting his decision as intentional and caused by an organisation different than the bibliographical order, i.e. the writer's logic, one should analyse all the indicated versions of the Ten jest $z$ ojczyzny mojej..., ale go nie lubie study (which was published also under the title Ten jest z Ojczyzny mojej..., ale go nie lubie $e^{20}$ ) and consider what form of the essay genre Gross fulfilled in them or what form he gave up, proposing the actual one instead. Since only the third and the fourth versions are available, I shall also include Gross' text which he wrote in the mid-1980s as a voice in a stormy debate - which historians remember almost exclusively as a monody - and a text from the late 1990s, almost two-thirds of which were altered. These two texts - bearing similar titles and with a common pedigree - mainly prove the evolution of their author's thinking, though they are also statements about Poles and Jews living side by side, and partly also about the 1941 anti-Jewish massacres. Though they display the features of a precursor or even prophetic texts, they do not include such a strong set of evidence as the one the researcher presented in Sasiedzi. When considering the style of the circumstance-based similarity which Gross used in them, one should bear in mind Adorno's argument. Similarly to Erasmus of Rotterdam, this author mocked the academic art of argumentation: "Its interpretations are not philologically definitive and conscientious; in principle, they are over-interpretations - according to the mechanized verdict of the vigilant intellect that hires out to stupidity as a watchdog against the mind"21. However, in order to notice that which basically only Gross was able to recognise, one should humbly accept the livery of a servant and listen to the admonitions of colleagues:

(...) rzetelny opis nawet najprzykrzejszych wydarzeń jest potrzebny. Zresztą to nie akademickie opisy są wykorzystywane przez wrogów obu narodów. Tak wykorzystuje się raczej wrażenia, uogólnienia i podejrzenia, pobudzone emocjonalnie legendy i stereotypy, o wiele bardziej nośne społecznie i chwytliwe politycznie niż te prace historyczne i socjologiczne, których autorzy chcą się czegoś dowiedzieć, wiedzą, co piszą, i odpowiadają za słowa w tym sensie, że sprawdzają, czy mają rację, i próbują swoje wypowiedzi uzasadnić. ${ }^{22}$

${ }_{18}$ J.T. Gross, Upiorna dekada. Trzy eseje o stereotypach na temat Żydów, Polaków, Niemców i komunistów 1939-1948, Kraków 1998.

19 J.T. Gross, Upiorna dekada. Trzy eseje o stereotypach na temat Żydów, Polaków, Niemców $i$ komunistów 1939-1948, Kraków 2007. The only piece of information about the changes introduced in the second edition was included underneath the main title in the form a note that read: "new, corrected and expanded edition". A quick glance at the table of contents indicates, however, that the differences mostly applied to the final chapter in the new edition, titled O kolaboracji [On Collaborationism], which departed from the 1998 edition.

${ }^{20}$ In the first version, the title of Gross' essay was included in Aneks and in Michnik's anthology, while in the second version it appeared in both editions of Upiorna dekada.

${ }^{21}$ T.W. Adorno, Esej jako forma, p. 80.

22 J. Karpiński, Asymetria..., p. 1006. 
[(...) a reliable description of even the most unpleasant events is necessary. In fact, it is not academic studies that are used by enemies of both nations. Towards that end people usually use impressions, generalisations and suspicions, emotion-driven legends and stereotypes, much more socially resonant and politically catchy than those historical and sociological studies whose authors want to learn something, they know what they write and they are responsible for their words in the sense that they verify whether they are right, and they try to justify their positions.]

Gross' views, recreated based on both versions of the essay on the history of Poles and Jews living side by side, were based on various methods of reaching the outcomes listed by Karpiński: generalisations, suspicions, and, most of all, emotion-driven stereotypes, which the author tried to verify. This is why Ten jest z ojczyzny mojej... was often attacked, while its book version, corrected and supported by additional pieces of evidence and with an altered introduction and conclusion, "passed almost unnoticed"23. What does actually differentiate both versions and why did Gross decide to, without any commentary, introduce in them corrections without withdrawing any of the two?

The 1986 version consists of three extensive parts. The first one, untitled, applies to, e.g., the above-discussed origins of the essay, and it explains the attitude of the writer, presumably composed in response to the above-discussed accusations. Gross placed his reflections within the area of focus of the Polish identity being reconstructed after years of captivity, making the Polish-Jewish relations during World War Two part of the reflection on the topic of the 200-year-long struggle of Poles for independence. That was not an obvious remark. Particularly because the line of thinking of Poles in the first half of the 20th century was dominated by history, there was not enough willingness or time to recall what those relations consisted of. The post-World-War-Two history of Poland unfolded in such a way that historians could have afforded to forget about that part of the past. Yet the essayist proposed to revise it and view it from the perspective of contemporary concerns, i.e. about the Polish identity. He calls himself a Pole; he recalls his mother, a member of the Polish szlachta, and his father, a Jew she was hiding. He primed the narrative perspective in such a way as to ensure everyone that he had the good of the nation in mind, not of the Jewish community: "I write this article with the conviction that for Poles the notion of PolishJewish relations during the war is a matter of momentous importance"24. At the same time, Gross utilises tomfoolery, pretending not to understand why

${ }^{23}$ J.T. Gross, Upiorna dekada..., 2nd edition, p. 9. The remark applied to the first edition of the collection. Yet, considering the contents of three studies devoted to Gross' works published in recent years by Magdalena Nowicka-Franczak, Paweł Dobrosielski, and Piotr Forecki, one should state the same about the second edition of Upiorna dekada. It did not cause any particular interest even among monographers. Cf. P. Dobrosielski, Spory o Grossa. Polskie problemy z pamięcią o Żydach, Warsaw 2017; M. Nowicka-Franczak, Niechciana debata. Spór o książki Jana Tomasza Grossa, Warsaw 2017; P. Forecki, Po Jedwabnem. Anatomia pamięci funkcjonalnej, Warsaw 2018.

24 J.T. Gross, Ten jest z ojczyzny mojej..., [in:] Przeciw antysemityzmowi..., p. 1009. 
the topic gives Poles the chills, or even makes them feverish; why they are opposed to talking about it in calm tones, debating reflectively, or making it a topic of study ${ }^{25}$.

The second part of the essay ${ }^{26}$ consists of the explanations by Jan Józef Lipski and Andrzej Szczypiorski regarding the lack of Poles' efficient aid for Jews during the Second World War. Lipski mainly emphasised the similarities of the experiences of both nations. In the well-known essay, titled Dwie ojczyzny, dwa patriotyzmy. Uwagi o megalomanii narodowej $i$ ksenofobii Polaków, in response to the question about whether enough was done to oppose the Holocaust, he used the notion of social margin - one disputed with full force by Gross in Sasiedzi - in order to prove that the phenomenon of szmalcowniks was occasional at best. Thus, it should be 'accepted' by the same virtue as one understands that goodness and evil exist side by side, and that weeds grow among flowers. Gross, however, was not convinced by such an explanation not only due to the error of perspective (what might that margin actually be?), but also due to the exclusion of that which was not marginal, i.e. the attitudes of regular Poles during Word War Two.

The other opinion discussed in this part, i.e. by Andrzej Szczypiorski, applied to the emotional costs of not helping. It is true, Szczypiorski argued, that Poles did not help as much as they should have, but who could expect heroism of people overcome with mortal fear for themselves and their loved ones? Further in that discussion Gross ironically paraphrased Szczypiorski's exceptionally naive argument: since Poles did not always help, they were pestered by remorse. The emotion was so severe, complicated, and experienced in utmost solitude that it would take at least Fyodor Dostoevsky to write about it. Gross had a counterargument: completely unnecessarily. If Poles had a conscience - being the devout Catholics they claim to be - they would have surely atoned for their sin of omission.

In the third part ${ }^{27}$, Gross mainly doubts the price and the value of the Polish occupation fear. While understanding that Poles were afraid of hiding Jews facing the threat to their lives and the lives of their families, the essayist wonders why they were not afraid of other activities "punishable under the German occupation by the death penalty"28, e.g. engaging in the

25 This applied to the following fragment, which was, in fact, rather flippant: "Why should some of us feel offended by the fact that there once existed some Polish szmalcowniks or that other Poles established ghetto benches? There is no such thing as collective responsibility so for us feeling guilty for the sins of some of our forefathers would be just as ridiculous as burdening Chancellor Kohl with the guilt for Auschwitz or the footballers of Dynamo Kyiv for Kolyma". As quoted in: J.T. Gross, Ten jest z ojczyzny mojej..., [in:] Przeciw antysemityzmowi..., p. 1010.

${ }^{26}$ One titled "O tym, jak brzmi obiegowa wersja polsko-żydowskich stosunków w czasie wojny i dlaczego jest nie do przyjęcia" ["On the common version of the Polish-Jewish relations during the war and why it is unacceptable"].

${ }_{27}$ Namely, “O tym, że antysemityzm rozpowszechniony w czasie okupacji wśród polskiego społeczeństwa był przyczyną, dla której Niemcy tak brutalnie i bezwyjątkowo mordowali Polaków za pomaganie Żydom, i dlaczego Polakom trudno jest o tym mówić" [“On that the anti-Semitism spread during the occupation among the Polish society was the reason why Germans so viciously and without exception slaughtered Poles for helping Jews, and why it is so difficult for Poles to talk about that"].

${ }^{28}$ Ibid., p. 1014. 
underground. The fact of comparing the underground and hiding Jews forced the author to draw a conclusion which revealed the weakness of the attitudes of Poles towards Jews during World War Two: "Activity in the underground entailed universal respect (...), lots of people engaged in those efforts, while few people were engaged in helping Jews and in their efforts they did not receive wide support" 29 . As Gross argues, perhaps if Poles had helped as often as they worked with the underground, helping would have become more common, it would not have caused the society to oppose it, and it would not have made it possible to transform into the object of trade, betrayal, and blackmail.

The second conclusion drawn in the previous part is much more intriguing and it applied to the introduction to the essay, which made the Polish-Jewish relations during the Second World War an element of Poland's reclaiming its Romantic ethos. Gross argues that the course of the restoration of the identity did not consider the division which emerged most acutely before World War Two - that Poland, up to that point aware of the fact that it had an ethnically diverse society, did not handle the fact that that society was a product of an accord between the majority and various minorities, between those who were strong and those who were weak. The monolith, which the society considered itself to be, was not able to absorb Shoah and adjust it to its Christian model of the redemptive meaning of a sacrifice. This is why the history of the Polish-Jewish relations were extracted from the public discourse for many years.

The major differences between the versions of Ten jest z ojczyzny mojej... published in the periodical and in a book form are as follows. The book version of the essay consists of three parts, while the introductory and the final parts differ from the original version published in Aneks. Only the middle part ("O tym, że antysemityzm rozpowszechniony w czasie okupacji wśród polskiego społeczeństwa był przyczyną...") is equivalent. The text's potential lies in the altered parts, which include crushing evidence in the form of uncirculated fragments of Karski's report (released in print as late as 1992) and extracts from Zygmunt Klukowski's journal. In combination with excerpts from underground press, they convey a terrifying degree of Polish anti-Semitism during World War Two, leaving no illusion as to why Poles did not rescue Jews in that period. In explaining the reasons for that, Gross referred to the 1966 study by Władysław Bartoszewski and Zofia Lewinówna, titled Ten jest z ojczyzny mojej. Polacy z pomoca Żydom 1939-1945, in which they collected nearly two hundred accounts from both sides of the wall. The authors' intention was to emphasise the mediating role of recollections, not anti-Semitism as such. For that, in fact, they used as a motto Słonimski's 1943 poem titled Ten jest $z$ ojczyzny mojej. In it, the poet depicted a utopian vision of brotherhood consisting of endless empathy towards the victims of wars ${ }^{30}$; the vision which Gross had in mind did not venture outside Poland and this is why it proved so difficult to fulfil. Unlike in the periodical version of the essay, in the book

\footnotetext{
${ }^{29}$ Ibid., p. 1026.

${ }^{30}$ Cf. A. Słonimski, Ten jest z ojczyzny mojej, [in:] Ten jest z ojczyzny mojej. Polacy z pomoca Żydom 1939-1945, eds. W. Bartoszewski, Z. Lewinówna, Kraków 1966, p. 5.
} 
he did not call for a change of the attitudes of Poles towards national identity and history. Instead of using the tone of an appeal, he used a view about the common circumstances of the Holocaust, for which both those past Poles and those alive now are responsible. Instead of unclear ironic statements vaguely placing guilt - e.g. "Why are some of us [emphasis - M. T.] supposed to feel offended by the fact that there once existed some Polish szmalcowniks or that other Poles established ghetto benches?"31 - Gross writes about shared guilt and shared responsibility, preparing the field for Sasiedzi: “(...) Shoah occurred among us [emphasis - M. T.]"32 He repeated with emphasis that Polishness did not necessarily consist of noble deeds (such as saving someone's life), but, more often, of deeds which were daring (the underground) and shady. What is noteworthy, though, is that the author of Upiorna dekada... was no longer interested in constructing identity or recreating the community, which made for extremely potent topics during the early Solidarity years, when most of the essays which I discussed at the beginning had been created. In the case of the previous version of Gross' study, one could talk about his hope for changes, his trying to fit into the Polish community, and triggering a factual debate about the "poor Christians" and the disliked neighbours. The quotation marks used by Gross in the following version - thus not only differentiating Słonimski's original content, but also stressing his own distance regarding the expression - actually signified a wall. In the anthology by Bartoszewski and Lewinówna, there were two sides to it, i.e. Polish and Jewish; in Gross' case, there was only one, the Jewish one, non-reducible to any Polish experiences.

4.

There is no doubt that the process of developing new versions of Ten jest z ojczyzny mojej... brought Gross closer to Sasiedzi, be it in terms of the form, the structure, or the material. Yet one should also attribute much value to those parts of the study which he decided to remove, considering them no longer valid, possibly even petty and excessively emotional. I am mainly referring to his private statement of faith in Polishness, combined with a short autobiographical story which emphasised the extensive influence his mother had on his life, as well as the unique nature of her relationship with his father, which could be referred to as a mésalliance if it had not been for the bourgeois scornful significance of the noun.

The autobiographical confession, further expanded in the 2018 collection of interviews with Gross by Aleksanda Pawlicka, constitutes the most sensitive moment in his essay as it applies to the broken fortunes of Gross' family, exposing him to a series of blows:

(...) kiedy niepoprawiona przeze mnie wersja tłumaczenia oksfordzkiego wykładu dotarła do kilku znajomych w Polsce, skomentowali mój tekst

31 J.T. Gross, Ten jest z ojczyzny mojej..., [in:] Przeciw antysemityzmowi..., p. 1010.

32 J.T. Gross, Upiorna dekada..., 2nd edition, p. 44. 
jako aberrację umysłową, że oto pod wpływem filmu „Shoah” odezwała się we mnie krew Machabeuszów. (...) mój artykuł jest reakcją na zew krwi piastowskiej raczej... ${ }^{33}$

[(...) when a version of the translation of my Oxford lecture not yet corrected by me reached some of my colleagues in Poland, they commented upon my text that it was a mental aberration, that lo and behold the film Shoah stirred in me my Maccabean blood. (...) my article is rather a reaction to the stirring of my Piast blood...]

Talking about a "stirring of blood", Gross did not, however, yield to the pressure to offer a brotherly statement, nor did he use that patriarchal argument to strengthen Słonimski's rhetoric. One should rather infer that through a series of figures shielding the 'I' - e.g. a warrior of the Maccabean clan or the descendent of the Piast dynasty - Gross became a heretic readying for a serious battle against an opponent who conceals their plan. According to Katarzyna Kuczyńska-Koschany:

Najwięksi, którzy o Zagładzie pisali, próbowali odnaleźć formę dostatecznie pojemną - w eseju, opowieści biograficznej, opowiadaniu, powieści, wierszu. Te formy albo się rozpadały, albo naruszały wiarygodność (bo jeszcze przez chwilę po Zagładzie wierzono w prawdopodobieństwo, mimesis itd.). Może najmniej rozpadał się esej, jego amorficzność okazywała się jedynie nadwątlać kategorię wiarygodności, a nie całkowicie podawać ją w wątpliwość. ${ }^{4}$

[The greatest who wrote about the Holocaust, tried to find a form sufficiently capacious - in the essay, the biographical story, the short story, the novel, or the poem. Those forms either fell apart or spoiled reliability (because after the Holocaust people still believed for a moment in probability, mimesis, etc.) Maybe the essay fell apart the least; its amorphous nature only appeared to weaken the category of reliability but not completely question it.]

In the case of Gross and his Holocaust essays, there was something more than the weakening of the category of reliability, mainly associated with the narrative of a witness. The main point was to find a form, a " $k o n d y$ cja" $^{\prime \prime 35}$ [state], as Kuczyńska-Koschany put it, which would enable the essayist to delay the moment of revealing the truth, to obfuscate, to play roles which were not always true, and to multiply and solve made-up conflicts. Then, the essay would mean a 'test ride', it would be a trial of academic thinking free of all burdens, which Adorno mentioned, especially from

${ }^{33}$ J.T. Gross, Ten jest z ojczyzny mojej..., [in:] Przeciw antysemityzmowi..., p. 1009.

${ }^{34}$ K. Kuczyńska-Koschany, Eseiści kondycji żydowskiej. Po Zagładzie: Maurice Blanchot i Bogdan Dawid Wojdowski, "Poznańskie Studia Polonistyczne. Seria Literacka" 2017, no. 30(50), p. 390.

${ }^{35}$ Ibid., p. 392. 
gravitating towards completeness and positive solutions. The negativity of Gross' essays is a quality which surely distinguishes them from all other texts of the mid-1980s. It is, however, progressive, involutionary, not direct, based on generalisations, tactical bluffs, jokes, irony - suffice it to say that due to these exact reasons and not the conceptual purity specific for Upiorna dekada, the text published in Aneks reads so well. Though the reasons why Gross supplemented it are understandable, the outcome itself is considerably weaker. It is in the 1986 essay that one will find all the 'faults' of the form, indicated by Adorno; it is specifically in it that "the violations of the orthodoxy of thought reveal something which orthodoxy secretly and objectively has intended to keep invisible" 36 . What is this? These are not domestic struggles or burning neighbours, i.e. the hatred-filled Polish-Jewish relations. Gross wrote about these expressis verbis. He somewhat en passant added in Aneks the remark that his intention was to comprehend the fear of hiding others, as he himself was "the fruit of that phenomenon" ${ }^{\prime 3}$. Why did Gross remove this fragment from later versions? Was it because it sounded too personal? One may assume that the story, somewhat explaining the circumstances of Gross' birth, constitutes a truly essayistic location in both texts by Gross - one which was opened and removed. One which meant to him just as much as all the later academic findings did. If not more.

\section{REFERENCES}

Adorno T.W., Sztuka i sztuki. Wybór esejów, transl. K. Krzemień-Ojak, selection and introduction K. Sauerland, Warsaw 1990.

Błoński J., Biedni Polacy patrza na getto, [in:] J. Błoński, Biedni Polacy patrza na getto, Kraków 2008, pp. 9-33.

Calderón Puerta A., Żukowski T., Wina obojętności, [in:] Opowieść o niewinności. Kategoria świadka Zagłady w kulturze polskiej (1942-2015), eds. A. Calderón Puerta, K. Chmieleska, M. Hopfinger et al., Warsaw 2018, pp. 345-387.

Descartes R., Rozprawa o metodzie, transl. W. Wojciechowska, Warsaw 1981, vol. 22.

Dobrosielski P., Spory o Grossa. Polskie problemy z pamięcią o Żydach, Warsaw 2017.

Forecki P., Po Jedwabnem. Anatomia pamięci funkcjonalnej, Warsaw 2018.

Gross J.T., Ten jest z ojczyzny mojej..., ale go nie lubie, [in:] Przeciw antysemityzmowi 1936-2009, vol. 2, selection and introduction by A. Michnik (ed.), Kraków 2010, pp. 1007-1029.

Gross J.T., Upiorna dekada. Trzy eseje o stereotypach na temat Żydów, Polaków, Niemców i komunistów 1939-1948, Kraków 1998.

Gross J.T., Upiorna dekada. Trzy eseje o stereotypach na temat Żydów, Polaków, Niemców i komunistów 1939-1948, Kraków 2007.

Jan Tomasz Gross w rozmowie z Aleksandra Pawlicka “...bardzo dawno temu, mniej więcej w zeszty piatek...", Warsaw 2018.

36 T.W. Adorno, Esej jako forma, p. 99.

37 J.T. Gross, Ten jest z ojczyzny mojej..., [in:] Przeciw antysemityzmowi..., p. 1009. 
Karpiński J., Asymetria, [in:] Przeciw antysemityzmowi 1936-2009, vol. 2, selection and introduction A. Michnik (ed.), Kraków 2010, pp. 997-1006.

Kuczyńska-Koschany K., Eseiści kondycji żydowskiej. Po Zagładzie: Maurice Blanchot i Bogdan Dawid Wojdowski, "Poznańskie Studia Polonistyczne. Seria Literacka" 2017, no. 30(50), pp. 385-399.

Nowicka-Franczak M., Niechciana debata. Spór o ksiązki Jana Tomasza Grossa, Warsaw 2017.

Smolar A., Tabu i niewinność, [in:] Przeciw antysemityzmowi 1936-2009, vol. 2, selection and introduction A. Michnik (ed.), Kraków 2010, pp. 1030-1075.

Śpiewak P., Szoah, drugi upadek, [in:] Przeciw antysemityzmowi 1936-2009, vol. 2, selection and introduction A. Michnik (ed.), Kraków 2010, pp. 934-948.

Zimand R., Piotun i popiót. Czy Polacy i Żydzi wzajem się nienawidza??, [in:] Przeciw antysemityzmowi 1936-2009, vol. 2, selection and introduction A. Michnik (ed.), Kraków 2010, pp. 1109-1160.

\section{SUMMARY}

This article discusses the special kind of Holocaust essay which, on the one hand, remains in opposition to academic texts and, on the other, is a text which resembles an autobiography, and which reveals its author's personal engagement in the discussed problem. By analysing Jan Tomasz Gross' study titled Ten jest z ojczyzny mojej..., ale go nie lubię and its consecutive printed versions, the author of this article discusses the benefit of engaging in essay-writing for the scholar, who fluctuates between the academic and non-academic discourses. To this end, she also discusses other Polish Holocaust essays published in the mid-1980s (by, e.g., Jan Błoński and Roman Zimand) and the theory of the essay by Theodor W. Adorno, which triggered Gross' formal and notional search.

\section{Keywords}

essay, Holocuast, antisemitism in Poland

Marta Tomczok - researcher of the Holocaust and its cultural references, assistant professor at the Faculty of Humanities, University of Silesia, editor-in-chief of the Narracje o Zagładzie yearly. Author of books: Trofea wyobraźni. O prozie Leo Lipskiego (2011), Metonimie Zagłady. O polskiej prozie lat 1987-2012 (2013), Czyja dzisiaj jest Zagłada? Retoryka - ideologia - popkultura (2017). She has published articles and reviews in, e.g., "Historyka Studia Metodologiczne", "Teksty Drugie", "Pamiętnik Literacki", "Ruch Literacki", "Porównania", "Poznańskie Studia Polonistyczne", "Poznańskie Studia Slawistyczne", "Zagadnienia Rodzajów Literackich", "Zagłada Żydów. Studia i Materiały". She collaborates with "Nowe Książki". Her research interests include the influence of new methodologies on Holocaust studies and other genocides, critical consideration of the aesthetics considered as past (postmodernism), new animism, and the environmental history of coal.

e-mail: martacuber@interia.pl 